\title{
Genetic markers in atherosclerosis: A review*
}

\author{
NEWTON E. MORTON \\ Population Genetics Laboratory, University of Hawaii, Honolulu
}

\begin{abstract}
Summary. There is a growing number of lipoprotein markers recognized by immunological, electrophoretic, and other biochemical methods, and a beginning has been made on studying their modes of inheritance and linkage relations. Suggestive but inconclusive evidence of a relation between the cerumen polymorphism and arteriosclerosis has been published. Associations of the ABO blood groups with cardiovascular disease and serum lipid levels have been established, but the exact relation to lipoproteins and atherosclerosis remains to be determined.
\end{abstract}

The subject of genetic markers in atherosclerosis is at the intersection of genetics, medicine, epidemiology, immunology, and biochemistry. The observations are scattered, sometimes preliminary or conflicting, and any review must soon be obsolete. Recognizing these limitations, I shall discuss the present state of our knowledge on antigenic polymorphisms of lipoproteins ( $\mathrm{Ag}, \mathrm{Lp}$, and $\mathrm{Ld}$ ), the controversial evidence of a relation between $\mathrm{Lp}$ and the HL-A locus, the cerumen polymorphism (W), electrophoretic variants of lipoproteins, available evidence on linkage of lipoprotein markers, and associations of the ABO blood groups with cardiovascular diseases and lipoproteins. Citation in this review does not imply credence, and my comments in the last section are deliberately speculative.

\section{Antigenic polymorphisms}

Three genetic polymorphisms of $\beta$-lipoprotein have been reported on the basis of the Ouchterlony method of double diffusion in agar gel. Allison and Blumberg (1961) discovered in a multiply transfused patient (C. de B.) an antiserum which they attributed to a polymorphic factor $\mathbf{A g}(+)$, later designated $\operatorname{Ag}(a)$. Subsequently, Hirschfeld (1963) showed that anti- $\mathrm{Ag}(\mathrm{a})$ is a mixture of three specificities, anti- $\mathbf{A g}\left(\mathrm{a}_{1}\right)$, anti- $\mathbf{A g}(\mathbf{x})$, and anti- $\mathrm{Ag}(\mathbf{z})$, which behave as a factor-union system. A fourth determinant, $\mathbf{A g}(\mathbf{y})$, is antithetical to $\mathrm{Ag}(\mathbf{x})$. Six

* This work has been supported by grants HL 16774 and GM17173 of the U.S. National Institutes of Health. The author is indebted to Drs K. Berg, J. Hirschfeld, L. Beckman, D. C. Shreffler, and F. Vogel for helpful comments on a first draft of this paper.
TABLE I

AG CHROMOSOME FREQUENCIES IN SWEDEN (after Hirschfeld and Rittner, 1969)

\begin{tabular}{l|c|c|c|c|c|c}
\hline $\begin{array}{l}\text { Chromosome } \\
\text { Frequency }\end{array}$ & $\mathrm{xa}_{1} \mathrm{z}$ & $\mathbf{0 a _ { 1 }}$ & $\mathrm{x}$ & $\mathrm{ya}_{12} \mathrm{z}$ & $\mathrm{ya}_{1}$ & $\mathrm{y}$ \\
\hline
\end{tabular}

TABLE II

GENE FREQUENCIES DEFINED BY $x, y$ FACTTORS OF Ag SYSTEM

(after Giblett, 1969)

\begin{tabular}{c|c|c|c}
\hline Alleles & $\begin{array}{c}\text { Caucasoid } \\
(\mathrm{N}=248)\end{array}$ & $\begin{array}{c}\text { Negroid } \\
(\mathrm{N}=54)\end{array}$ & $\begin{array}{c}\text { Mongoloid } \\
(\mathrm{N}=1205)\end{array}$ \\
\hline $\begin{array}{c}\mathrm{Ag}^{\mathbf{x}} \\
\mathrm{Ag}^{\mathbf{y}}\end{array}$ & 0.23 & 0.69 & 0.73 \\
& 0.77 & 0.31 & 0.27 \\
\hline
\end{tabular}

alleles appear to account for the population frequencies and segregation in families (Table I). The $\mathrm{Ag}(\mathrm{z})$ factor is apparently a subtype of $a_{1}$, since chromosomes $x z$ and $y z$ have not been observed. All reported alleles have either the $x$ or $y$ factor, but not both. From limited gene frequency data, $\mathbf{A g}^{\mathbf{x}}$ is the common allele in Africa and Asia, while $\mathbf{A g}^{\mathbf{y}}$ predominates in Europe (Table II).

The symbol $\mathrm{Ag}$ has been suggested for all $\beta$ lipoprotein antigens detected by isoimmunization (Bütler, 1967). Patients with thalassaemia are especially good producers of antiserum, perhaps because of the associated splenomegaly (Blumberg et al, 1964). The relation of many of these antisera to the Ag system defined by $a_{1}, x, y$, and $z$ is unclear (Hirschfeld, 1972). Dausset et al (1968) report 
TABLE III

Lpa GENE FREQUENCIES (after Berg, 1968)

\begin{tabular}{l|r|c}
\hline \multicolumn{1}{c|}{ Population } & $\mathrm{N}$ & Gene frequency \\
\hline Norwegians & 1109 & 0.1948 \\
Hadza, Tanzania & 107 & 0.1912 \\
Easter Islanders & 106 & 0.0434 \\
Indians, Labrador & 234 & 0.0086 \\
\hline
\end{tabular}

several apparent crossovers between the $\mathrm{Ag}(\mathrm{a})$ and $\mathrm{Ag}(\mathrm{t})$ factors (Berg, 1972).

European workers have obtained convincing evidence that $\mathrm{Ag}$ is a regular phenotype system. However, Okochi (1967) reported several exceptions to the dominant inheritance of $\mathrm{Ag}(\mathrm{y})$ and the postulated complementarity of $\mathbf{A g}(\mathbf{y})$ and $\mathbf{A g}(\mathbf{x})$. Antibodies to $\beta$-lipoprotein are exclusively located in the 7-S- $\gamma$ globulin fraction and are quite stable, though often weak or poly-specific. The antigens, however, are notoriously labile, whether stored at $4^{\circ} \mathrm{C}$ or frozen. It is not clear at the present time whether exceptions to the theory of Hirschfeld with respect to $\operatorname{Ag}\left(a_{1}, x, y, z\right)$ are the result of technical problems or are real.

A little-studied LDL polymorphism was defined by anti-Ld(a), discovered in the serum of a frequently transfused haemophiliac (Berg, 1965). It is anomalous in reacting strongly at $4^{\circ} \mathrm{C}$ and $20^{\circ} \mathrm{C}$, but not at $37^{\circ} \mathrm{C}$. Nevertheless, the precipitin was found to reside in the $\gamma_{G}$ fraction. The inheritance of $\operatorname{Ld}(a)$ is autosomal dominant, with a gene frequency of 0.24 in Norway. By the criterion of isoimmunization it would conventionally (if ambiguously) be called an Ag factor, but its relation to the $\mathrm{Ag}$ locus is unknown. There is no association or linkage between the $\mathrm{Lp}$ and $\mathrm{Ld}$ systems (Berg, 1966). An antiserum that may define $\mathrm{Ld}(\mathrm{b})$ was reported by Berg and Bearn (1970).

The Lp system is by far the best studied, and in recent years the most severely attacked. Berg (1963) immunized rabbits with human serum or $\beta$-lipoprotein; later horses, baboons, and sheep were shown also to produce $\mathrm{Lp}$ anti-sera. Isoimmunization has not been successful, though $\mathrm{Lp}(\mathrm{a}-)$ baboons produce specific antisera against $L p(a)$. Conversely, anti-Ag is never heteroimmune. The only $\mathrm{Lp}$ antigen that has been much studied is $L p(a)$; there is an $L p(x)$ defined by a horse antiserum which precipitates in a different band from $\mathrm{Lp}(\mathrm{a})$ but is always concordant with it (Bundschuh, 1964). The $\mathrm{Lp}^{2}$ gene frequency is lower in Orientals than in Caucasians and Negroes (Table III). Chimpanzees, orangutans, baboons, and Rhesus monkeys are polymorphic for the $\mathrm{Lp}(\mathrm{a})$ antigen, which is qualitatively different in the Rhesus monkey from man and the other primates tested.

The strongest evidence for dominant inheritance of $\mathrm{Lp}(\mathrm{a})$ comes from 574 families (Wendt, 1966). Only 1 of 547 children from $L p(a-) \times L p(a-)$ matings was $\mathrm{Lp}(\mathrm{a}+)$; on the basis of several polymorphisms parentage was not excluded. Rider, Levy, and Frederickson (1970) identified the 'sinking' pre- $\beta$ lipoprotein (which in the ultracentrifuge does not float at the density 1.006) as $\mathrm{Lp}(\mathrm{a})$, and confirmed that this component segregated as a dominant trait in 51 kindreds. Both Wood (1969) and Rittner (1970) found a clearly bimodal distribution of the $\mathrm{Lp}$ (a) antigen in serum, and Wood found that $\mathrm{Lp}(\mathrm{a}+)$ persons could be divided by radial immunodiffusion into two groups, which appeared to correspond to homozygotes and heterozygotes. Albers, Chen, and Aladjem (1972) were unable to demonstrate the $L p(a)$ antigen in the sera of $L p(a-)$ persons after 110-fold concentration. All these observations provide strong evidence for dominant inheritance of the $\mathrm{Lp}(\mathrm{a})$ antigen.

Against the prevailing view two criticisms have been raised. Schultz and Shreffler (1972) used preparative ultracentrifugation and absorption on sepharose gel to isolate what they considered to be purified $L p(a)$ substance, even for individuals classified by them as $\mathrm{Lp}(\mathrm{a}-)$. Noting that an isoimmune anti-Lp(a) has never been found, they question the dominant inheritance of $\operatorname{Lp}(a)$. Interpretation of their results depends critically on identity of components recognized by immunological and biophysical techniques (Harvie and Schulz, 1973). With their antisera 13 per cent of children from $L p(a-) \times L p(a-)$ matings were classified as $L p(a+)$. They note that 'their original anti- $\mathrm{Lp}(\mathrm{a})$ antisera was prepared against the serum of an individual who was consistently classified $\mathrm{Lp}(\mathrm{a}-)$ on Ouchterlony double diffusion.'

Berg (1972) stressed the negligible frequency of exceptional children (1/547) in European family data and the failure of Albers et al (1972) to de- 9 monstrate $\mathrm{Lp}(\mathrm{a})$ substance in concentrated sera $D$ from $\mathrm{Lp}(\mathrm{a}-)$ individuals. Albers and Hazzard (1974) have subsequently reported a J-shaped dis- N tribution of purported $\mathrm{Lp}$ (a) substance in the general population, including individuals classified $N$ as $L \mathrm{p}(\mathrm{a}-)$. A recent report (Walton et al, 1974), $\mathrm{\omega}$ which for the first time used sheep antisera and rocket electrophoresis, makes the situation seem 0 even more confused. A J-shaped distribution is again found, with many but not all persons typed as $\stackrel{\mathscr{Q}}{-}$ $\mathrm{Lp}(\mathrm{a}-)$ in Ouchterlony gels appearing to have $\mathrm{Lp}(\mathrm{a})$ substance after the serum is concentrated. Schultz et al (1974) now favour a dominant gene with nearly 
complete penetrance, based partly on a bimodal distribution of antigen concentration and partly on family material (Sing, Schultz, and Shreffler, 1974).

The important genetic question here is not whether $\mathrm{Lp}(\mathrm{a}-)$ individuals have trace amounts of $\mathrm{Lp}(\mathrm{a})$ substance, or whether this is an artefact of preparation or incompletely absorbed antisera. It is rather the bimodality of $\operatorname{Lp}(\mathrm{a})$ that is at issue. The only workshop on the $\mathrm{Lp}$ system was held in 1966, and the proceedings are not readily accessible (Wendt, 1966). Annual HL-A workshops have demonstrated their utility for resolving questions of techniques and serum quality (e.g. Dausset and Colombani, 1973). The answer to the $\mathrm{Lp}$ debate can only be found in the laboratory. The solution may have implications for the Ag and other lipid antigens and for the apparent homology of $L p(a)$ antigen, the sinking pre-beta lipoprotein detected in the ultra-centrifuge, the pre- $\beta_{1}$ band in agarose gel electrophoresis (Heiberg and Berg, 1974), and perhaps the double beta-lipoprotein of Seegers et al (1965).

\section{Evidence of a relation between $L p$ and HL-A systems}

Berg (1971) has reported two suggestions of a relation between the $\mathrm{Lp}$ and HL-A systems. First, skin grafts were observed to survive longer when donors and recipients were of the same $\mathrm{Lp}$ type (Berg et al, 1968). This study has not been repeated. Secondly, the amino acid compositions of HL-A and $L p(a)$ are remarkably similar by the difference index (DI) of Metzger et al (1968). Whereas the lowest DI observed by Metzger et al among 630 pairs of proteins was 9.1 , with 13.9 for the $\alpha$ and $\beta$ chains of human haemoglobin, Berg (1971) found 6.8 to 9.0 for the comparison of $\mathrm{Lp}(\mathrm{a})$ and HL-A and 6.7 to 8.4 for the DI between $L p(a)$ and murine H-2 antigen. This led Berg (1972) to raise the question whether $L p(a)$ lipoprotein is primarily synthesized as a component of cell membranes and whether it functions as a histocompatibility antigen.

This suggestion was severely attacked by Schultz and Shreffler (1972) on the grounds that there is no cross-reaction between anti- $\mathrm{Lp}(\mathrm{a})$ and anti-HL-A sera and there is frequent recombination between the two loci. Clearly the study on Lp incompatibility in skin grafts must be repeated. Structural homology of the same order as between myoglobin and haemoglobin or between the unlinked loci for $\alpha$ and $\beta$ haemoglobin can only be established by amino acid sequencing. From immunological evidence Langdon (1974) has proposed that serum apopro-
TABLE IV

GENE FREQUENCY FOR DRY CERUMEN (after Matsunaga, 1959)

\begin{tabular}{l|r|c}
\hline \multicolumn{1}{c|}{ Population } & $\mathrm{N}$ & Gene frequency \\
\cline { 1 - 2 } Northern Chinese & 216 & 0.9789 \\
Koreans & 381 & 0.9622 \\
Mongols & 1099 & 0.9375 \\
Japanese & 2317 & 0.9150 \\
Southern Chinese & 708 & 0.8603 \\
Micronesians & 458 & 0.6092 \\
Formosan aborigines & 1420 & 0.5347 \\
Ainus & 30 & 0.3651 \\
Germans & 514 & 0.1764 \\
American Negroes & 63 & 0.0694 \\
\hline
\end{tabular}

teins are the major lipophilic proteins of plasma membranes.

\section{Cerumen polymorphism (W)}

Beginning with Miyake (1932), Japanese workers showed that ear wax exists in two forms: grey, brittle, and dry, vs. brown, sticky, and wet, with intermediate or ambiguous types occurring with a frequency of only about $0.5 \%$ among Japanese (reviewed in Matsunaga, 1962). The two types may be distinguished soon after birth and are stable throughout life. From data on several hundred Japanese families they were found to be governed by a pair of alleles $\mathrm{W}, \mathrm{w}$, where the recessive $w w$ determines dry cerumen. Among 634 children from dry $\times$ dry matings, there was none with wet cerumen. The frequency of dry cerumen is higher in northern Mongoloids than in other populations (Table IV).

The cerumen polymorphism appears to control the development of apocrine sweat glands and the nature of their secretory products. Most persons with wet cerumen develop axillary odour at puberty. Nagashima (1934) demonstrated multiple histological differences in the ceruminous glands of Japanese with wet and dry ear wax. On the basis of investigations in Caucasoid and Japanese populations dry cerumen contains $18 \%$ lipid and $43 \%$ protein, while wet cerumen has about $50 \%$ lipid and $20 \%$ protein. Since the cholesterol fraction of the lipid material is similar, the absolute amount of cholesterol excreted by persons with wet cerumen is inferred to be greater. Modern methods to characterize lipids and lipoproteins do not seem to have been applied to cerumen.

On the basis of these observations, Matsunaga (1962) suggested that the two cerumen types differ in lipid metabolism and that, 'an association between ear wax types and some internal diseases, such as arteriosclerosis' should be sought. Subsequently such an association between wet cerumen and arteriosclerosis without hypertension was briefly 
TABLE V

TESTS FOR ASSOCIATION WITH CERUMEN TYPE

\begin{tabular}{|c|c|c|c|}
\hline Miyahara et al (1969) & Wet & Dry & Total \\
\hline $\begin{array}{l}\text { Arteriosclerosis without hypertension } \\
\text { Control } \\
\text { Total } \\
\chi_{1}^{2}=22.82 \\
\text { relative risk wet/dry }=1.84\end{array}$ & $\begin{array}{r}93 \\
1206 \\
1299\end{array}$ & $\begin{array}{r}201 \\
4798 \\
4999\end{array}$ & $\begin{array}{r}294 \\
6004 \\
6298\end{array}$ \\
\hline $\begin{array}{l}\text { Miyahara and Matsunaga }(1966) \\
\text { Hypertensive arteriosclerosis }+ \text { heart } \\
\text { dieease } \\
\text { Control } \\
\text { Total } \\
\chi_{1}^{2}=3.97 \\
\text { relative risk wet/dry }=0.69\end{array}$ & $\begin{array}{r}36 \\
311 \\
347\end{array}$ & $\begin{array}{r}224 \\
1327 \\
1551\end{array}$ & $\begin{array}{r}260 \\
1638 \\
1898\end{array}$ \\
\hline
\end{tabular}

reported (Miyahara and Matsunaga, 1966). Since then only another abstract (in Japanese) has appeared (Miyahira et al, 1969). The relevant data are given in Table V. In their first and more detailed report the authors did not comment on the barely significant decrease of hypertensive arteriosclerosis and heart disease with wet cerumen. In an unstated number of observations, they found no relation between cerumen type and serum cholesterol.

It is conventional in studies of disease association to regard the first claim with due suspicion. At this point the relevance of cerumen types to lipid metabolism and arteriosclerosis can neither be asserted nor rejected. Since cerumen types can be classified by routine otoscopic examination (Petrakis, Molokow, and Tepper, 1967), it should be easier to settle this question than to discuss it.

\section{Electrophoretic variants}

The Ag polymorphism has not been detected electrophoretically. Some genetic diseases of lipid metabolism are enzymatic (e.g. LCAT deficiency) or have other metabolic errors besides hypolipaemia and hypocholesterolaemia (e.g. hypochromic anaemia, Hooft's disease). With these exceptions, genes for lipid variation determine the regulation or structure of lipoproteins which may be characterized electrophoretically in agarose gel, though originally cholesterol and triglyceride concentrations of whole serum, and subsequently ultracentrifugation, were used. Except for the pre- $\beta_{1}$ trait, the genetic forms appear to be idiomorphic (i.e. with gene frequencies less than 0.01). Berg (1972) cautions that the pre$\beta_{1}$ band may be apparent on electrophoresis of $\mathrm{Lp}(\mathrm{a}-)$ sera, since lipoproteins other than the $\mathrm{Lp}(\mathrm{a})$ antigen may occur in the region of the $L p(a)$ lipoprotein, both upon disc electrophoresis and ultracentrifugation. Despite such problems, it seems reasonable to denote by $\mathrm{Lp}$ the major gene controlling the $\mathrm{Lp}(\mathrm{a})$ antigen, the pre- $\beta_{1}$ band, sinking pre$\beta$, and perhaps the double $\beta$-lipoprotein (Seegers et al, 1965). The capitalized symbol Lp may be used for the corresponding phenotype, even when the mode of inheritance is in doubt.

Using this convention, the various electrophoretic variants presumed to be sometimes genetic are indicated in Table VI. Alpha lipoprotein is divisible on agarose gel electrophoresis into $\alpha_{1}$ and $\alpha_{2}$ bands, but no variant specific to one of these bands has been reported. Other variants are probably heterogeneous. It would be hard to exaggerate the uncertainty of some of these entities. Even for the more common variants, where many cases have been studied, no careful genetic analysis has been performed. One can only conjecture the reasons for this: (1) variations in technique among investigators and changes in time, so that a moderately large series of families has not been studied with the same

TABLE VI

ELECTROPHORETIC VARIANTS

\begin{tabular}{|c|c|c|c|c|c|c|}
\hline Lipoprotein & $\begin{array}{l}\text { Variant } \\
\text { Allele }\end{array}$ & Name of Variant & $\begin{array}{c}\text { Fredrickson } \\
\text { Type }\end{array}$ & $\begin{array}{l}\text { Presumed In- } \\
\text { heritance of } \\
\text { Clinical Form }\end{array}$ & $\begin{array}{l}\text { Poly- } \\
\text { morphic }\end{array}$ & Notes \\
\hline $\begin{array}{l}\text { Pre- } \beta_{1} \\
\text { Beta (LDL) }\end{array}$ & $\begin{array}{l}\text { Lp } \\
\text { Hc }\end{array}$ & $\begin{array}{l}\text { Lp(a), pre- } \beta_{1} \text {, sinking pre- } \beta \\
\text { Hypercholesterolaemia } \\
\text { (hyper- } \beta \text {-lipoproteinaemia) }\end{array}$ & $\overline{\text { II }}$ & $\begin{array}{l}\text { Dom. } \\
\text { Dom. }\end{array}$ & $\stackrel{+}{0}$ & $\begin{array}{l}\text { Pre- } \beta \text { sometimes raised (same } \\
\text { allele? }\end{array}$ \\
\hline Alpha (HDL) & $\mathbf{H a}$ & Hyper- $\alpha$-lipoproteinaemia & 一 & Dom. & 0 & $\begin{array}{l}\text { One case with reduced, slow } \\
\text { pre- } \beta\end{array}$ \\
\hline Chylomicrons & $\mathbf{H k}$ & Hyperchylomicronaemia & & Rec. & 0 & $\begin{array}{l}\text { Heterozygote has reduced } \\
\text { LPL }\end{array}$ \\
\hline Floating $\beta$ (VLDL) & $\mathbf{F b}$ & Floating $\beta$-lipoproteinaemia & III & Dom. & $\begin{array}{l}0 \\
0\end{array}$ & 'Broad beta', overlaps Ht \\
\hline $\begin{array}{l}\text { Pre- } \beta(\text { VLDL }) \\
\text { Beta }\end{array}$ & $\begin{array}{l}\mathbf{H t} \\
\mathrm{Db}\end{array}$ & $\begin{array}{l}\text { Hypertriglyceridaemia } \\
\text { Double } \beta \text {-lipoprotein }\end{array}$ & IV & Dom. & 0 & Same as $L p(a) ?$ \\
\hline Beta & $\begin{array}{l}\mathbf{b} \\
\mathbf{a}\end{array}$ & $\begin{array}{l}\text { A- } \beta \text {-lipoproteinaemia } \\
\text { An- } \alpha \text {-lipoproteinaemia }\end{array}$ & $\overline{-}$ & $\begin{array}{l}\text { Rec. } \\
\text { Rec. }\end{array}$ & $\begin{array}{l}0 \\
0\end{array}$ & $\begin{array}{l}\text { Absence of LDL } \\
\text { Tangier disease }\end{array}$ \\
\hline Chylomicrons + pre $-\beta$ & Hv & Hyper-VLD-lipoproteinae- & $\mathrm{V}$ & Rec., dom. & 0 & \\
\hline$\beta+$ pre $-\beta$ & Ch1 & $\begin{array}{l}\text { Combined hyperlipopro- } \\
\text { teinaemia }\end{array}$ & - & Dom. & 0 & Pre $-\beta$ more raised than $\beta$ \\
\hline
\end{tabular}


TABLE VII

LOD SCORES FOR LIPID MARKERS

\begin{tabular}{|c|c|c|c|c|c|c|c|c|c|}
\hline \multirow{2}{*}{ System } & \multicolumn{2}{|c|}{$\mathrm{Ag}$} & \multirow{2}{*}{ Reference } & \multicolumn{2}{|c|}{$\mathbf{L p}_{\mathrm{p}}$} & \multirow{2}{*}{ Reference } & \multicolumn{3}{|c|}{ Hc } \\
\hline & $\theta=0.1$ & $\theta=0.3$ & & $\theta=0.1$ & $\theta=0.3$ & & $\theta=0.1$ & $\theta=0.3$ & Reference \\
\hline $\begin{array}{l}\text { Ag } \\
\text { Lp } \\
\text { Hc } \\
\text { ABO } \\
\text { ADA } \\
\text { AcP } \\
\text { C'3 } \\
\text { Fy } \\
\text { Gc } \\
\text { Gm } \\
\text { Hp } \\
\text { HL-A } \\
\text { Inv } \\
\text { Jk } \\
\text { Lu } \\
\text { Le } \\
\text { MN } \\
\text { PGM } 1 \\
\text { P } \\
\text { PTC } \\
\text { Rh }\end{array}$ & $\begin{array}{r}X \\
-2.16 \\
-3.55 \\
N D \\
-8.56 \\
0.24 \\
-0.79 \\
-3.09 \\
-6.28 \\
-6.08 \\
-7.08 \\
-9.03 \\
-31.98 \\
-2.79 \\
-6.90 \\
-0.25 \\
-0.69 \\
-21.29 \\
-10.90 \\
-10.93 \\
0.02 \\
-13.60\end{array}$ & $\begin{array}{c}X \\
-0.35 \\
-0.61 \\
\text { ND } \\
-0.52 \\
0.17 \\
0.37 \\
-0.29 \\
-0.89 \\
-0.12 \\
-0.24 \\
-0.47 \\
-3.40 \\
0.14 \\
-1.02 \\
-0.02 \\
-0.02 \\
-1.46 \\
-1.21 \\
-1.63 \\
0.01 \\
0.10\end{array}$ & $\begin{array}{l}5 \\
7 \\
2 \\
2 \\
2 \\
2 \\
2 \\
2 \\
2 \\
2 \\
2 \\
2 \\
2 \\
2 \\
2 \\
2 \\
2 \\
2 \\
2 \\
2 \\
2\end{array}$ & $\begin{array}{c}\mathrm{X} \\
\\
-0.21 \\
\text { ND } \\
-0.88 \\
\text { ND } \\
-0.82 \\
0.02 \\
-1.59 \\
-0.90 \\
-1.50 \\
-2.46 \\
-3.55 \\
0.04 \\
\text { ND } \\
\text { ND } \\
-1.95 \\
\text { ND } \\
-0.38 \\
\text { ND } \\
-0.00\end{array}$ & $\begin{array}{c}\mathrm{X} \\
\\
-0.02 \\
\text { ND } \\
-0.15 \\
\text { ND } \\
-0.13 \\
0.01 \\
0.02 \\
0.38 \\
-0.31 \\
-0.45 \\
-0.61 \\
0.01 \\
\text { ND } \\
\text { ND } \\
-0.30 \\
\text { ND } \\
-0.10 \\
\text { ND } \\
0.34\end{array}$ & $\begin{array}{l}2 \\
2 \\
2 \\
2 \\
2 \\
2 \\
8 \\
2 \\
6 \\
2 \\
2 \\
2 \\
2\end{array}$ & $\begin{array}{c}\text { ND } \\
-2.61 \\
\text { X } \\
\text { ND } \\
\text { ND } \\
\text { ND } \\
-1.44 \\
\text { ND } \\
\text { ND } \\
-10.92 \\
\text { ND } \\
\text { ND } \\
\text { ND } \\
\text { ND } \\
-4.06 \\
\text { ND } \\
-6.69 \\
-7.06 \\
\text { ND } \\
\text { ND } \\
-10.46\end{array}$ & $\begin{array}{c}\text { ND } \\
-0.52 \\
\text { X } \\
\text { ND } \\
\text { ND } \\
\text { ND } \\
0.82 \\
\text { ND } \\
\text { ND } \\
-2.59 \\
\text { ND } \\
\text { ND } \\
\text { ND } \\
\text { ND } \\
-0.03 \\
\text { ND } \\
-0.81 \\
-1.41 \\
\text { ND } \\
\text { ND } \\
-2.25\end{array}$ & $\begin{array}{l}3 \\
3 \\
3 \\
3\end{array}$ \\
\hline
\end{tabular}

ND, not done; $X$, identical.

List of references: 1 : Heiberg and Berg, 1974; 2: Edwards, 1974; 3: Ott et al, 1974; 4: Jackson et al, 1974; 5 : Berg, 1967; 6: Gedde-Dahl and Berg, 1965; 7: Rittner, 1966; 8: Dausset et al, 1968.

protocol; (2) greater interest of lipid investigators in biochemical aspects; (3) unavailability of a geneticist competent to perform complex segregation analysis of a multivariate quantitative trait, under age and sex adjustment and incomplete ascertainment; and (4) deficiencies in the published techniques for family analysis, which have only recently become adequate for analyses of the required complexity (Elston and Stewart, 1971; Rao, Morton, and Yee, 1974; Morton and MacLean, 1974; MacLean, Morton, and Lew, 1975).

Whatever the reasons for neglect of genetic aspects of lipoprotein variation in the past, it is to be hoped that critical analyses will soon be done which will substantiate or refute the conjectures in Table VI. Until the major genes are delineated, debate about polygenic variation is sterile (Jensen and Blankenhorn, 1972).

\section{Linkage}

Once a gene has been identified by segregation analysis, its formal genetics can be elucidated through linkage studies (Morton, 1955). The method of choice is lod scores, the logarithm of the probability ratio for recombination fractions $\theta<1 / 2$ (linkage) and 1/2 (no linkage). Older studies often used sib pair and u-score methods, which are inefficient and unreliable for linkage data in man. We assume here that the markers are factor-union systems (complete penetrance, dominant expression).

Of the lipoprotein markers, only $\mathrm{Ag}, \mathrm{Lp}$, and $\mathrm{Hc}$ have been studied for linkage. Table VII gives lod scores $(z)$ for $\theta=0.1$ and 0.3 . A negative value argues against linkage at that value of $\theta$, convincingly if $\mathrm{z}<-1$. A lod score greater than 2 is suggestive of linkage, and $z>3$ is conclusive evidence for linkage.

None of the lipoprotein markers has been securely assigned to a linkage group. However, Jackson et al (1974) reported one kindred with large satellites on a $\mathrm{G}$ chromosome identified as number 21 . There was no recombination between the marker and the $\mathrm{Ag}$ system, giving a lod score of 2.1 for $\theta=0$. As the authors note, this is sufficiently suggestive of linkage to warrant further study. However, there is no evidence of linkage between $\mathrm{Ag}$ and SOD-1 (superoxide dismutase dimer), which has been localized in somatic cell hybrids on chromosome 21 (Berg, Beckman, and Beckman, 1975). Either $\mathrm{Ag}$ is not on chromosome 21, or it is not close to SOD-1.

$\mathrm{Ag}$ is unlikely to be on chromosome 1 (large negative scores with $F y, P G M_{1}$, and $R h$ ), or on chromosome 16 with $\mathrm{Hp}$ or chromosome 6 with HL-A. The information about $\mathrm{Lp}$ is much less, while only a few systems are informative for Hc. Close linkage of the $\mathrm{Ag}, \mathrm{Lp}$, and HL-A systems is excluded, as is close linkage of $\mathrm{Lp}$ and Hc. There 
are no data for many test loci (including PTC, Ak, $\mathrm{Pi}, \mathrm{Lu}$, etc. which are not tabulated).

Table VII indicates limitations both of theory and practice in human linkage studies. In practice the use of $\theta=0.1$ and 0.3 adequately summarizes evidence against linkage; however, if linkage is suspected, a good estimate can be obtained only if the interval from 0 to $1 / 2$ is mapped (say, at increments of 0.05 ). In theory, we would like to test for linkage not to particular loci but to their linkage group, given information about the location of one or more loci on it. For example, the information from Fy, $\mathrm{Rh}$, and $\mathrm{PGM}_{1}$ can be combined to test the hypothesis of linkage on chromosome 1 and if the evidence is significant, to assign the marker to its most likely location.

Some linkage data were not included in Table VII because insufficient information was available to derive lod scores. Matsunaga (1962) gave sib-pair data which argue against close linkage of the cerumen system to ABO, MN, P, and PTC. Mohr and Reinskou (1963) and Mohr and Berg (1963) published on linkage relations of $\mathrm{Lp}$ using what they called the Morton-Smith method. Unfortunately this gives a posterior probability which cannot be efficiently combined with any other body of data. I should not wish to be associated with that method, which I have never used nor advocated, and which represents Smith's Bayesian analysis of lod scores (Morton, 1962). Linkage was not suggested.

It would not be surprising if the structural loci for lipoproteins, presently recognized through antigenic markers, were unlinked to the predominantly regulatory loci detected as electrophoretic variants. By analogy with immunoglobulins and haemoglobins, linkage of some of the lipoproteins seems likely. More complex genetic architecture involving lipoprotein and regulator linkages is possible, and could only be detected through linkage studies.

\section{ABO associations}

A bewildering number of diseases appears to be associated with $\mathrm{ABO}$ blood groups (Vogel, 1970; Allan, 1971, 1973; Mourant, Kopec, and Domaniewska-Sobczak, 1971; Vogel and Helmbold, 1972). The evidence ranges from stomach cancer (with more than 100 publications indicating a $22 \%$ higher risk for individuals of type $A$ than for type $O$ ) to a single report of borderline significance on raised diastolic blood pressure in type $O$ (Nance et al, 1965). Between these two extremes of uncertainty are several apparent associations between ABO groups and cardiovascular disease, mostly in the direction of a greater risk for types $A+B+A B$ relative to type $O$. In support of this is a reported excess of type $O$ in selected populations such as athletes and healthy aged (Jorgensen and Schwartz, 1968). The analytical unit in these studies has been the $2 \times 2$ contingency table of disease $(+$ or - ) by blood group (e.g. $\mathrm{O}$ or non-O). If the numbers in the Table are $\left|\begin{array}{ll}a & b \\ c & d\end{array}\right|$, the relative risk is $a d / b c$ (Woolf, 1955).

Tests for association between $\mathrm{ABO}$ blood groups and cardiovascular disease by this method are given in Table VIII. The highly significant association between rheumatic fever and non-O (also ABH nonsecretor) is thought to be a result of repression of growth or virulence of haemolytic streptococci by water-soluble $\mathbf{H}$ blood group substance (Clarke, 1961). Though 14 of the 17 studies are concordant in direction the heterogeneity in magnitude is highly significant. The association remains highly

TABLE VIII

ABO ASSOCIATIONS WITH DIABETES AND CARDIOVASCULAR DISEASE (after Vogel and Helmbold, 1972) $\mathbf{A}+\mathbf{B}+\mathbf{A B}$ ys. 0

\begin{tabular}{|c|c|c|c|c|c|c|c|c|c|}
\hline Disease & $\begin{array}{l}\text { No. of } \\
\text { Studies }\end{array}$ & $\begin{array}{c}\text { No. of } \\
\text { Patients }\end{array}$ & $\begin{array}{l}\text { No. of } \\
\text { Controls }\end{array}$ & $\begin{array}{l}\text { Mean } \\
\mathrm{ad} / \mathrm{bc}\end{array}$ & $\chi_{i}^{*}$ & $\begin{array}{c}\chi^{2} \text { for } \\
\text { Heterogeneity }\end{array}$ & $\mathbf{F}$ & $\begin{array}{l}\text { Studies } \\
\text { with } \\
\mathrm{ad} / \mathrm{bc}>1\end{array}$ & $\begin{array}{c}\text { Observed } \\
\text { Range }\end{array}$ \\
\hline $\begin{array}{l}\text { Rheumatic fever } \\
\text { Ischaemic heart disease } \\
\text { Diabetes mellitus } \\
\text { Arteriosclerosis obliterans } \\
\text { (Weiss, 1972) } \\
\text { Venous thromboembolism } \\
\text { Arteriosclerotic psychosis } \\
\text { Hypertension } \\
\text { Congenital heart disease }\end{array}$ & $\begin{array}{r}17 \\
12 \\
20 \\
1 \\
5 \\
1 \\
6 \\
4\end{array}$ & $\begin{array}{r}6589 \\
2763 \\
15778 \\
502 \\
1026 \\
271 \\
3468 \\
2836\end{array}$ & $\begin{array}{r}179385 \\
218727 \\
612819 \\
2583 \\
287246 \\
49979 \\
199252 \\
124654\end{array}$ & $\begin{array}{l}1.234 \\
1.174 \\
1.072 \\
1.468 \\
1.604 \\
0.771 \\
0.964 \\
1.029\end{array}$ & $\begin{array}{c}57.40^{* * *} \\
15.03^{* * *} \\
16.24 \\
14.86^{* * *} \\
48.89^{* * *} \\
4.56^{* *} \\
0.97 \\
0.42\end{array}$ & $\begin{array}{l}32.85^{* *} \\
29,18^{* *} \\
42.20^{* *} \\
\overline{22.54 * * *} \\
16.50^{* *} \\
4.87\end{array}$ & $\begin{array}{c}27.96^{* * *} \\
5.67^{*} \\
7.31^{*} \\
-\overline{8.68 *} \\
\overline{0.29} \\
0.26\end{array}$ & $\begin{array}{r}14 \\
9 \\
17 \\
-5 \\
2 \\
3\end{array}$ & $\begin{array}{l}0.87-1.59 \\
0.89-1.70 \\
0.81-1.39 \\
- \\
1.26-2.91 \\
0.48-1.15 \\
0.68-1.41\end{array}$ \\
\hline
\end{tabular}

$0.01<P<0.05$

$* * 0.001<\mathrm{P}<0.01$

$* * * P<0.001$. 
TABLE IX

ABO BLOOD GROUPS AND SERUM CHOLESTEROL (after Vogel and Helmbold, 1972)

\begin{tabular}{|c|c|c|c|c|c|c|c|}
\hline \multirow{2}{*}{ Population } & \multirow{2}{*}{ Author } & \multirow{2}{*}{$\mathrm{N}$} & \multicolumn{4}{|c|}{ Mean cholesterol $\pm \mathrm{SE}$} & \multirow{2}{*}{$\begin{array}{c}\text { Significance of } \\
\mathrm{A}+\mathrm{AB} \text { vs. } \mathrm{B}+\mathrm{O}\end{array}$} \\
\hline & & & A & B & $\mathrm{O}$ & AB & \\
\hline $\begin{array}{l}\text { British } \\
\text { British }\end{array}$ & $\begin{array}{l}\text { Oliver, Cumming, and } \\
\text { Geizerova, } 1969 \\
\text { Langman et al, } 1969\end{array}$ & $\begin{array}{l}6000 \\
515 \% \\
3440\end{array}$ & $\begin{array}{l}212 \pm 0.9 \\
248.0 \\
258.4\end{array}$ & $\begin{array}{c}204 \pm 1.7 \\
238.0 \\
240.5\end{array}$ & $\begin{array}{c}206 \pm 0.8^{*} \\
238.7 \\
250.7\end{array}$ & $\begin{array}{l}213 \pm 3.4 \\
236.2 \\
252.7\end{array}$ & \multirow{6}{*}{$\begin{array}{l}\text { Sig. only for esterified } \\
\text { cholesterol } \\
<10^{-3} \\
\text { Sig. }\end{array}$} \\
\hline \multirow{2}{*}{$\begin{array}{l}\text { Indians in } \\
\text { Singapore } \\
\text { Swedes }\end{array}$} & \multirow{2}{*}{$\begin{array}{l}\text { Banerjee and Saha, } 1969 \\
\text { Beckman and Olivecrona, } \\
1970\end{array}$} & 325 & 173.9 & 161.9 & 163.7 & 158.3 & \\
\hline & & 285 & $3.85 \pm 0.07$ & $3.73 \pm 0.13$ & $3.70 \pm 0.08$ & $3.56 \pm 0.19$ & \\
\hline \multirow{3}{*}{$\begin{array}{l}\text { Thais } \\
\text { Greeks } \\
\text { Greeks }\end{array}$} & \multirow{3}{*}{$\begin{array}{l}\text { Flatz, } 1970 \\
\text { Polychronopoulou, Miras, } \\
\text { and Trichopoulos, } 1974 \\
\text { Mayo, Fraser, and } \\
\text { Stamatoyannopoulos, } \\
1969\end{array}$} & 715 & 2.183 & 2.156 & 2.141 & 2.174 & \\
\hline & & 83 & 359.7 & 285.6 & 332.4 & 367.5 & \\
\hline & & 532 & $2.71 \pm 3.04$ & $-1.75 \pm 8.83$ & $-6.15 \pm 1.82$ & $5.68 \pm 3.66$ & \\
\hline
\end{tabular}

* Corrected according to Oliver et al, 1969.

significant when this heterogeneity is taken into account by an $\mathrm{F}$ test.

At a lower level of significance, non-O is associated with increased risk to myocardial infarction, venous thromboembolism, and perhaps arteriosclerosis obliterans and angina pectoris, but not arteriosclerotic psychosis, hypertension, or congenital heart disease. There is a suggestion that the $A_{2}$ gene behaves more like $O$ than $A_{1}$ in these associations (Allan, 1971). A later report on $A B O$ groups and hypertension claimed a barely significant association with type $A$, using the approximate method of Mantel and Haenszel (1959) instead of the more reliable method of Woolf or its smallsample modification (Morton and Chung, 1959). Preston and Barr (1964) and Kerr et al (1966) reported a significant excess of Factor VIII in persons of types $A$ and $B$ relative to group $O$, which with the evidence for thromboembolism led Weiss (1972) to suggest that $\mathrm{ABO}$ type affects risk for thrombosis, but not atherosclerosis and other components of cardiovascular disease.

Equivocal evidence for a relation between $\mathrm{ABO}$ type and atherosclerosis is supported by lipid and lipoprotein associations. Several studies show a significantly higher serum cholesterol in persons of type $A$ and $A B$ than in $O$ and $B$ persons (Table IX). Ledvina and Kellen (1962) found the serum concentration of $\beta$-lipoprotein to be in the order $\mathrm{A}_{1}>\mathrm{O}$, $A B>A_{2}, B$, and Magis $(1957,1960)$ reported that ether extraction in the presence of heparin gives a higher concentration of lipids from types $A$ and $A B$ than from $B$ and $O$. A recent publication finds group $\mathrm{A}$ and $\mathrm{AB}$ persons considerably more frequent in hyperlipoproteinemia type II than type IV (Table $\mathrm{X}$ ). If this result is confirmed, it signifies that blood group A is more directly related to lipoprotein type than to serum cholesterol, and as the
TABLE X

AEO BLOOD GROUPS IN HYPERLIPOPROTEINEMIA (Polychronopoulou et al, 1974)

\begin{tabular}{l|c|c|c}
\hline \multicolumn{1}{c|}{ ABO group } & Type II & Type IV & Total \\
\hline A+AB & 30 & 12 & 42 \\
B+ O & 18 & 23 & 41 \\
\hline Total & 48 & 35 & 83 \\
\hline
\end{tabular}

$\chi_{1}^{2}=6.45$

Relative risk of $\mathrm{II}=3.19$.

authors note, 'credence would be added to the classification of hyperlipidemias according to the lipoprotein pattern.'

Associations between G6PD electrophoretic variants (Long, Wilson, and Frenkel, 1967) and the Kidd blood groups (Medalie et al, 1973) have been reported in ethnic mixtures. The possibility of confounding with environmental factors is not excluded, and these associations have not been found in other populations.

\section{Discussion}

Alpha-lipoprotein, which predominates in the newborn (Wille and Phillips, 1971), is usually thought to have no clinical significance. On the contrary, there is a substantial decrease in $\alpha$ cholesterol in patients with heart disease, leading Brunner, Manelis, and Altman (1967) to assume, 'that the first step in the development of atherogenic lipid patterns is a redistribution of the serum cholesterol from the alpha- to the beta-lipoproteins.' The variant hyper- $\alpha$-lipoproteinemia may be more frequent in diabetes (Wille and Aarseth, 1973).

With the possible exception of $\alpha$-lipoprotein, there is no evidence that any of the lipoprotein. 
variants is associated with decreased risk of atherosclerosis. There are even some claims of specific associations. Dahlen et al (1972) reported on pre$\beta_{1}$-lipoprotein, dominantly inherited, with increased risk for coronary heart disease. Berg et al (1973) identified this lipoprotein as $L p(a)$. In other material it appears to be a risk factor (Berg, Dahlén, and Frick, 1974) independent of hyper- $\beta$ lipoproteinemia (Heiberg and Berg, 1974).

Progress in understanding the role of genetic markers in atherosclerosis requires solution of several problems:

(1) It must be determined whether the antigenic polymorphisms are factor-union systems, and how $\mathrm{Lp}(\mathrm{a})$ relates to the electrophoretic band and ultracentrifugal class with which homology has been inferred. There appears to be urgent need for workshops of the kind which have elucidated the HL-A system.

(2) Complex segregation analysis (which in addition to a major locus specifically allows for common environment and polygenic variation, incomplete ascertainment, and covariance adjustment) should be applied to pedigree data on quantitative variants, both antigenic and electrophoretic, instead of making an arbitrary dichotomy into 'normal' and 'affected'. If the dichotomy is justified, it will be revealed by segregation analysis of the quantitative trait.

(3) The role of the cerumen polymorphism in lipid metabolism should be determined, and the reported association with arteriosclerosis should be confirmed or refuted. Such study is best done in Mongoloid populations with substantial frequencies of dry cerumen.

(4) Resolution of genetic entities should be sought not only by immunological and biochemical means, but also by linkage analysis.

(5) Serum cholesterol is apparently raised in groups $A$ and $A B$, which have been reported to be susceptible to hyperlipoproteinemia type II. The relation of $A B O$ groups (including $A_{1}, A_{2}$ subtypes) and of $\mathrm{ABH}$ secretion to serum proteins should be elucidated.

(6) Homeostasis for serum lipoproteins would tend to reduce one component when another is specifically raised. Therefore, an increase in $\beta$ or pre- $\beta$-lipoprotein could lower the concentration of $\alpha$-lipoprotein, as various authors have observed (Barclay, 1972; Wille and Aarseth, 1973; Rhoads, Gulbrandsen, and Kagan, 1976). The associations between $\mathrm{ABO}$ blood groups and cardiovascular diseases could be explained if the $A+B+A B$ types have faster blood coagulation (leading to thromboembolism), but $A+A B$ increases the synthesis or half-life of $\beta$-lipoprotein (leading to atherosclerosis) and to a lesser degree of pre- $\beta$-lipoprotein (giving a smaller increase for diabetes). This simple hypothesis (which probably does violence to the physiology of all three diseases) has only one merit: that by predicting an increased concentration of $\beta$-lipoprotein, a lesser increase for pre- $\beta$-lipoprotein, and a decreased concentration of $\alpha$-lipoprotein in persons of types $A+A B$, it is not difficult to test.

(7) If this hypothesis is true, the $\mathrm{ABH}$ substances may act either at the cell surface (alcohol-soluble $\mathrm{ABH}$ ) or in collodial suspension (water-soluble $\mathrm{ABH})$. In the latter event the lipoprotein concentration would depend also on the Se locus which controls $\mathrm{ABH}$ secretion.

(8) Evidence suggesting that atheromas develop because mucopolysaccharides in the arterial wall sequestrate plasma LDL (Adams and Bayliss, 1973) makes one wonder whether other mucopolysaccharides (such as ABH water-soluble substance of secretors) or glycolipids (such as ABH alcoholsoluble substances) can differentially affect this process. Subtyping of A may be important, because of the intermediacy of $A_{2}$ between $A_{1}$ and $O$. Complex interactions could occur if, for example, intimal fibrosis were promoted in group $\mathrm{O}$ by the mechanism which leads to increased risk for bleeding ulcers in persons of this type, while formation of atheromas after internal fibrosis was favoured in persons of types $A$ and $A B$. Such an opposition would tend to give negative or conflicting evidence in arteriosclerosis, compared with myocardial infarction and thromboembolism in which type $O$ is underrepresented.

(9) Rejnek et al (1963) reported that $\alpha_{1}$-lipoprotein from pregnant women either inhibits cell growth, or is associated with such an inhibitor. If persons of types $A+A B$ have decreased levels of $\alpha$-lipoprotein, as predicted, they might on this account be expected to have a high incidence of neoplasms, as observed. The ABO association is especially well shown for cancers of the gastrointestinal tract, where we should note that the $A B O$ and Se loci (besides their effects on antigens and antibodies) interact in expression of intestinal alkaline phosphatase (Beckman, 1964).

(10) The existence of large registries of normal people, typed for ABO and under surveillance for atherosclerosis and other diseases, has not been exploited either in countries with national medical services or in those with large numbers of military conscripts, as the U.S. during the second world war. Control for stratification of the population is essential in such study. An excellent control is provided by dizygous twins discordant for the $\mathrm{ABO}$ groups. Adequate, though less elegant, controls 
are available for much larger samples, though limitations are imposed by errors of typing or recording and lack of $A_{1}, A_{2}$ subtyping. Only epidemiological investigation provides the evidence which can confirm or refute predictions from biochemical and genetic studies.

\section{REFERENCES}

Adams, C. W. M. and Bayliss, O. B. (1973). Acid mucosubstances underlying lipid deposits in ageing tendons and atherosclerotic arteries. Atherosclerosis, 18, 191-195.

Albers, J. J., Chen, C., and Aladjem, F. (1972). Human serum lipoproteins. Evidence for three classes of lipoproteins in $\mathrm{S}_{\mathrm{f}} 0-2$. Biochemistry, 11, 57-63.

Albers, J. J. and Hazzard, W. R. (1974). Immunochemical quantification of human plasma $\mathrm{Lp}$ (a) lipoprotein. Lipids, 9, 15-26.

Allan, T. M. (1971). ABO blood-groups and myocardial infarction. Lancet, 1, 238-239.

Allan, T. M. (1973). ABO blood-groups and atherosclerosis. Atherosclerosis, 18, 347-351.

Allison, A. C. and Blumberg, B. S. (1961). An iso-precipitation reaction distinguishing human serum protein types. Lancet, 1, 634-637.

Banerjee, B. and Saha, N. (1969). Blood groups and serumcholesterol. Lancet, 2, 961.

Barclay, M. (1972). Lipoprotein class distribution in normal and diseased states. In Blood Lipids and Lipoproteins: Quantitation, Composition, and Metabolism, pp. 585-704. Ed. by G. J. Nelson. Wiley-Interscience, New York.

Beckman, L. (1964). Association between human serum alkaline phosphatase and blood groups. Acta Genetica et Statistica Medica, 14, 286-297.

Beckman, L. and Olivecrona, T. (1970). Serum-cholesterol and $\mathrm{ABO}$ and Lewis blood-groups. Lancet, 1, 1000.

Berg, K. (1963). A new serum type system in man: the Lp system. Acta Pathologica et Microbiologica Scandinavica, 59, 369-382.

Berg, K. (1965). A new serum type system in man: the Ld system Vox Sanguinis, 10, 513-527.

Berg, K. (1966). Lack of linkage between the Lp and Ld serum systems. Experientia, 22, 660-663.

Berg, K. (1967). Lack of linkage between the Lp and Ag serum systems. Vox Sanguinis, 12, 71-74.

Berg, K. (1968). The Lp system. Series Haematologica, 1, 111136.

Berg, K. (1971). Compositional relatedness between histocompatibility antigens and human serum lipoproteins. Science, 172, 1136-1138.

Berg, K. (1972). The Lp system-interpretations and views. In Human Genetics (Proceedings of the 4th International Congress of Human Genetics), pp. 352-362. Ed. by J. DeGrouchy, F. J. G. Ebling, and I. W. Henderson. Excerpta Medica, Amsterdam.

Berg, K. and Bearn, A. G. (1970). Antibodies to inherited $\beta$-lipoprotein antigens in the serum of multiply transfused patients. Clinical Genetics, 1, 104-120.

Berg, K., Ceppellini, R., Curtoni, E. S., Mattiuz, P. L., and Bearn, A. G. (1968). The genetic antigenic polymorphisms on human serum $\beta$-lipoprotein and survival of skin grafts. In Advance in Transplantation, pp. 253-255. Ed. by J. Dausset, J. Hamburger, and G. Mathé. Munksgaard, Copenhagen.

Berg, K., Dahlen, G., Erikson, C., Frick, H., Furberg, C., and Wiljasalo, M. (1973). Pre- $\beta$-lipoprotein: relationship to angiographically proven coronary heart disease and to $\mathrm{Lp}(\mathrm{a})$ lipoprotein. In Proceedings of the 3rd International Symposium on Atherosclerosis, Berlin. In the press.

Berg, K., Dahlén, G., and Frick, M. H. (1974). Lp(a) lipoprotein and pre- $\beta_{1}$-lipoprotein in patients with coronary heart disease. Clinical Genetics, 6, 230-235.

Berg, K., Beckman, G., and Beckman, L. (1975). A search for linkage between the $\mathrm{Ag}$ and (dimeric) superoxide dismutase (SOD-1) loci. In Human Gene Mapping. Ed. by Bergsma. Birth Defects: Original Article Series, 11, No. 3, 67-70.

Blumberg, B. S., Alter, H. J., Riddell, N. M., and Erlandson, M. (1964). Multiple antigenetic specificities of serum lipoproteins detected with sera of transfused patients. Vox Sanguinis, 9, 128145.
Brunner, D., Manelis, G., and Altman, S. (1967). Physical activity, lipoproteins and ischemic heart disease. Pathologia et Microbiologia, 30, 648-652.

Bundschuh, G. (1964). Anti-Lp(a,x) vom Pferd. Ar̈ztl Lab, 10, 309.

Bütler, R. (1967). Polymorphisms of the human low-density lipoproteins (editorial). Vox Sanguinis, 12, 2-17.

Clarke, C. A. (1961). Blood groups and disease. In Progress in Medical Genetics, vol. 1, pp. 81-119. Ed. by A. G. Steinberg and A. G. Bearn. Grune and Stratton, New York.

Dahlen, G., Ericson, C., Furberg, C., Lundkvist, L., and Svärdsudd, K. (1972). Studies on an extra pre-beta-lipoprotein fraction Acta Medica Scandinavica, Suppl. 531, pp. 1-29.

Dausset, J. and Colombani, J. (1973). (Eds.) Histocompatibility Testing 1972. Munksgaard, Copenhagen.

Dausset, J., Contu, L., Feingold, N., and Barge, A. (1968). Indépendance du système d'histocompatibilité HL-A et des systèmes de groupes des bêta-lipoprotéines $\mathrm{Lp}$ et $\mathrm{Ag}$. Nouvelle Revue Française d'Hématologie, 868-870.

Edwards, J. H. (1974). Total lods for linkage anaysed by the New York Blood Center and Birmington Computer Programs. In Human Gene Mapping, pp. 187-202. Ed. by D. Bergsma. Intercontinental Medical Book Corporation, New York.

Elston, R. C. and Stewart, J. (1971). A general model for the genetic analysis of pedigree data. Human Heredity, 21, 523-542.

Flatz, G. (1970). Serum-Cholinesterin, ABO-Blutgruppen, and Hamoglobintyp. Humangenetik, 10, 318-328.

Gedde-Dahl, T. and Berg, K. (1965). Linkage in man. The Inv and Lp serum type systems. Nature (London), 208, 1126.

Giblett, E. R. (1969). Genetic Markers in Human Blood. F. A. Davis. Philadelphia.

Harvie, N. R. and Schultz, J. S. (1973). Studies on the heterogeneity of human $\mathrm{Lp}$ lipoproteins and the occurrence of double Lp lipoprotein variants. Biochemical Genetics, 9, 235-245.

Heiberg, A. and Berg, K. (1974). On the relationship between $\mathrm{Lp}$ (a) lipoprotein, "sinking pre- $\beta$-lipoprotein" and inherited hyper$\beta$-lipoproteinaemia. Clinical Genetics, 5, 144-156.

Hirschfeld, J. (1963). Investigations of a new anti-Ag antiserum with particular reference to the reliability of Ag typing by microimmuno-diffusion tests in agar gel. Science Tools, 10, 45-54.

Hirschfeld, J. (1972). The Ag system-present concepts and immunogenetic models. In Protides of the Biological Fluids, pp. 157160. Ed. by H. Peeters. Pergamon Press, Oxford.

Hirschfeld, J. and Rittner C. H. (1969). Inheritance of the $\mathrm{Ag}(\mathbf{x})$ $\operatorname{Ag}(y),\left(a_{1}\right)$ and $\operatorname{Ag}(z)$ antigens. Vox Sanguinis, 16, 146-154.

Jackson, L., Falk, C. T., Allen, F. H., Jr., and Barr, M. (1974). A possible gene assignment to chromosome 21. In Human Gene Mapping. (New Haren Conference 1973), Birth Defects: Original Article Series, pp. 100-102. Intercontinental Medical Book Corporation, New York and London.

Jensen, J. and Blankenhorn, D. H. (1972). The inheritance of familial hypercholesterolemia. American fournal of Medicine, $\mathbf{5 2}$, 499-516.

Jorgensen, G. and Schwartz, G. (1968). Weitere Untersuchungen zur Frage der Unterschiedlichen Selektionswertigkeit im ABOBlutgruppensystem. Humangenetik, 5, 254-260.

Kerr, C. B., Preston, A. E., Barr, A., and Biggs, R. (1966). Further studies on the inheritance of factor VIII. British fournal of Haematology, 12, 212-233.

Langdon, R. G. (1974). Serum lipoprotein apoproteins as major protein constituents of the human erythrocyte membrane. Biochimica et Biophysica Acta, 242, 213-228.

Langman, M. J., Elwood, P. C., Foote, J., and Pyrie, D. R. (1969) ABO and Lewis blood-groups and serum-cholesterol. Lancet, 2, 607-609.

Ledvina, M. and Kellen, J. (1962). Relations of the $\beta$-lipoproteins of the serum to the blood groups. Folia Haematologica (Leipzig) 79, 382-388.

Long, W. K., Wilson, S. W., and Frenkel, E. P. (1967). Association between red cell glucose-6-phosphate dehydrogenase variants and vascular diseases. American fournal of Human Genetics, 19, 35-53.

MacLean, C. J., Morton, N. E., and Lew, R. (1975). Analysis of family resemblance IV. Operational characteristics of segregation analysis. American fournal of Human Genetics, 27, 365-367.

Magis, C. (1957). Influence du groupe sanguin sur le taux d'extraction des lipides du sérum. Comptes Rendus Hebdomadaires des Séances l'Académie des Sciences, 244, 2432-2434.

Magis, C. (1960). Thesis, Paris University. 
Mantel, N. and Haenszel, W. (1959). Statistical aspects of the analysis of data from retrospective studies of disease. Fournal of the National Cancer Institute, 22, 719-748.

Matsunaga, E. (1959). Polymorphism in ear-wax types and its anthropological significance. Zinruigaku Zassi (f. Anthrop Soc. of Nippon), 67, 171-184.

Matsunaga, E. (1962). The dimorphism in human normal cerumen Annals of Human Genetics, 25, 273-286.

Mayo, O., Fraser, G. R., and Stamatoyannopoulos, G. (1969), Genetic influences on serum cholesterol in two Greek villages. Human Heredity, 19, 86-99.

Medalie, J. H., Papier, C., Goldbourt, U., Levene, C., Dreyfull, F. Oron, D., Neufeld, H. N., and Riss, E. (1973). Blood groups and hypertension. Israel fournal of Medical Science, 9, 989-997.

Metzger, H., Shapiro, M. B., Mosimann, J. E., and Vinton, J. E. (1968). Assessment of compositional relatedness between proteins. Nature (London), 219, 1166-1168.

Miyahara, M., Iimura, O., Ashie, T., and Matsunaga, E. (1969). Ear-wax types and diseases of internal medicine with special reference to arteriosclerosis. Fapanese fournal of Human Genetics, $14,250-251$.

Miyahara, M. and Matsunaga, E. (1966). Association of ear-wax types with susceptibility to arteriosclerosis-a preliminary report. Annual Report, National Institute of Genetics fapan, 17, 127-129.

Miyake, S. (1932). On the inheritance of wet cerumen. (In Japanese.) fibi-Inkyoka-Kai-Kaiko, 42, 713.

Mohr, J. and Berg, K. (1963). Genetics of the Lp serum types: associations and linkage relations. Acta Genetica et Statistica Medica, 13, 343-348.

Mohr, J. and Reinskou, T. (1963). Genetics of the Gc serum types; associations and linkage relations. Acta Genetica et Statistica Medica, 13, 328-333.

Morton, N. E. (1955). Sequential tests for the detection of linkage. American fournal of Human Genetics, 7, 277-318.

Morton, N. E. (1962). Segregation and linkage. In Methodology in Human Genetics, pp. 17-52. Ed. by W. J. Burdette. HoldenDay, San Francisco.

Morton, N. E. and Chung, C. S. (1959). Are the MN blood groups maintained by selection? American fournal of Human Genetics, 11, 237-251.

Morton, N. E. and MacLean, C. J. (1974). Analysis of family resemblance. III. Complex segregation of quantitative traits. American fournal of Human Genetics, 26, 489-503.

Mourant, A. E., Kopec, A. C., and Domaniewska-Sobczak, K. (1971). Blood-groups and blood-clotting. Lancet, 1, 223-228.

Nagashima, T. (1934). Ceruminous glands and cerumen in Japanese, with special reference to axillary odour. (In Japanese.) fapanese fournal of Dermatology and Urology, 36, 690.

Nance, W. E., Krieger, H., Azevedo, E., and Mi, M. P. (1965), Human blood pressure and the ABO blood group system: an apparent association. Human Biology, 37, 238-244.

Okochi, K. (1967). Serum lipoprotein alotypes $\mathbf{A g}(x)$ and $\mathbf{A g}(y)$ in Japanese. Vox Sanguinis, 13, 319-326.

Oliver, M. F., Cumming, R. A., and Geizerova, H. (1969). Serumcholesterol and $\mathrm{ABO}$ and Rhesus blood-groups. Lancet, 2, 605609.

Ott, J., Schrott, H. G., Goldstein, J. L., Hazzard, W. R., Allen, F. H., Jr., Falk, C. T., and Motulsky, A. G. (1974). Linkage studies in a large kindred with familial hyper-cholesterolemia, American fournal of Human Genetics, 26, 598-603.

Petrakis, N. L., Molokow, K. T., and Tepper, D. J. (1967). Cerumen in American Indians: genetic implications of sticky and dry types. Science, 158, 1192-1193.
Polychronopoulou, A., Miras, C. J., and Trichopoulos, D. (1974). Lipoprotein types, serum cholesterol, and ABO blood groups. British fournal of Preventive and Social Medicine, 28, 60-62.

Preston, A. E. and Barr, A. (1964). The plasma concentration of factor VIII in the normal population. II. The effects of age, sex, and blood group. British fournal of Haematology, 10, 238-245.

Rao, D. C., Morton, N. E., and Yee, S. (1974). Analysis of family resemblance. II. A linear model for familial correlation. American fournal of Human Genetics, 26, 331-359.

Rejnek, J., Bednarik, T., Rerarabkova, E., and Dolezal, A. (1963). Investigations of the influence of sera from pregnant women on the growth of cell cultures in conjunction with the occurrence of abnormal $\alpha_{1}$-lipoprotein. Clinica Chimica Acta, 8, 108-115.

Rhoads, G. G., Gulbrandsen, C. L., and Kagan, A. (1976). Serum lipoproteins and coronary heart disease in a population study of Hawaii Japanese men. New England fournal of Medicine. In the press.

Rider, A. K., Levy, R. I., and Frederickson, D. S. (1970). "'Sinking" pre-beta-lipoprotein and the Lp antigen. Council on Arteriosclerosis. Circulation, 41-42, Suppl. 3, 10 (abstr.), p. 34.

Rittner, C. H. (1966). Bestehen Beziehungen Zwischen dem Agund dem Lp-system? Zeitschrift fïr Immunitätsforschung und experimentelle Therapie, 130, 229-241.

Rittner, C. (1970). Die lipoprotein-(LDL-) polymorphismus des menschlichen serums. Thesis, Bonn University.

Schultz, J. S. and Shreffler, D. C. (1972). Genetics and immunochemistry of the Lp antigen of human serum. In Human Genetics (Proceedings of the 4th International Congress of Human Genetics), pp. 345-351. Ed. by J. De Grouchy, F. J. G. Ebling, and I. W. Henderson. Excerpta Medica, Amsterdam.

Schultz, J. S., Shreffler, D. C., Sing, C. F., and Harvie, N. R. (1974). The genetics of the Lp antigen: I. Its quantiation and distribution in a sample population. Annals of Human Genetics, 38, 39-46.

Seegers, W., Hirschhorn, K., Burnett, L., Robson, E., and Harris, H. (1965). Double beta-lipoprotein: a new genetic variant in man. Science, 149, 303-304.

Sing, C. F., Schultz, J. S., and Shreffler, D. C. (1974). The genetics of the Lp antigen: II. A family study and proposed models of genetic control. Annals of Human Genetics, 38, 47-56.

Vogel, F. (1970). ABO blood groups and disease. American fournal of Human Genetics, 22, 464-475.

Vogel, F. and Helmbold, W. (1972). Blutgruppen and Genkoppelung. In Humangenetik: Ein kurzes Handbuch, Band 1/4: Blutgruppen, pp. 307-330. Ed. by P. E. Becker. Georg Thieme Verlag, Stuttgart.

Walton, K. W., Hitchens, J., Magnani, H. N., and Khan, M. (1974). A study of methods of identification and estimation of $\mathrm{Lp}(\mathrm{a})$ lipoprotein and of its significance in health, hyper-lipidaemia and atherosclerosis. Atherosclerosis, 20, 323-346.

Weiss, N. S. (1972). ABO blood type and arteriosclerosis obliterans American fournal of Human Genetics, 24, 65-70.

Wendt, G. G. (1966). (Ed.) Internationale Lp-Arbeitstagung. Institut für humangenetik des Phillipps-Universität, Marburg/Lahn.

Wille, L. E. and Aarseth, S. (1973). Demonstration of hyper- $\alpha-$ lipoproteinemia in three diabetic patients. Clinical Genetics, 4 281-285.

Wille, L. E. and Phillips, G. B. (1971). Demonstration of an atypical pre- $\beta$-lipoprotein in human serum. Clinical Genetics, 2 , 242-247.

Wood, C. (1969). Genetically determined variant in human $\beta-$ lipoprotein. Archives of Disease in Childhood, 44, 544.

Woolf, B. (1955). On estimating the relation between blood group and disease. Annals of Human Genetics, 19, 251. 